AFRICAN

\title{
Gabon-China relations: towards a more cautious partnership*
}

\author{
By Jean-Pierre Cabestan** \\ Department of Political Science \\ Hong Kong Baptist University, SAR Hong Kong
}

\begin{abstract}
As early as in the 1970s, the then Gabonese president Omar Bongo Ondimba, although very close to France, decided to diversify his country's external partnerships. The development of dynamic diplomatic and, since the 1990s, economic relations with China was part of this strategy. And since he succeeded his father in 2009, Ali Bongo has continued and even deepened this diversification policy. Yet, Gabon's strategy as well as domestic political pressure, have contributed to setting limits to its diplomatic and economic partnership with China. In other words, Gabon offers an instructive case of how domestic politics and foreign policy priorities can influence an African country's relations with the world second great power and economy. Having said that, much wealthier and less populated than many other African nations and enjoying more options than many of them, Gabon may remain a special case.
\end{abstract}

*This research was funded by the Research Grant Council of Hong Kong Special Administrative Region (GRF No. HKBU 240110)

**Jean-Pierre Cabestan is Head of Department at the Department of Political Science at Hong Kong Baptist University in SAR Hong Kong. 


\section{Introduction}

Gabon is still seen by some observers as the symbol of the Françafrique, this cosy and often incestuous relationship between France and its former colonies in Africa (Yates, 1996; Benquet, 2011). Although relations between Libreville and Paris have remained very close and France continues to hold regular summits with its African partners, the old, traditional Françafrique has been gone for a long time, including in Gabon. As early as the 1970s, the then Gabonese president Omar Bongo Ondimba, although handpicked by the French government, decided to diversify his country's external partnerships. The development of dynamic diplomatic and, since the 1990s, economic relations with China was part of this strategy (Michel and Beuret 2010: 147-75). And since he succeeded his father in 2009, Ali Bongo has continued and even deepened this diversification policy. As a result, in the last twenty years, Gabon-China trade has decupled, Chinese infrastructure projects and investments in this resource-rich African country have surged; economic and political co-operation has consolidated, turning Gabon into a privileged destination for Chinese business and political leaders.

Yet, Gabon's strategy of international diversification and, more recently, the pressure of a more assertive civil society have contributed to setting limits to its diplomatic and economic partnership with China. Elected under dubious circumstances with only 42 per cent of the vote in 2009 and contested by influential opposition figures, President Ali Bongo needs to convince the electorate of his achievements before the next election in 2016. Simultaneously, some disappointments with Chinese companies have also contributed to this change of mind. In 2012-2013, two major "push backs" occurred (Addax and Bélinga), as a result of Chinese companies' unwelcomed practices or inability to fulfil their commitment. And more globally, in spite of the mega-projects in which China has been involved, its image among the Gabonese elites and society has remained controversial, creating a distance, if not a mistrust. As a result, Ali Bongo has appeared less enthusiastic than his father about privileging co-operation with China. In other words, Gabon offers an instructive case of how domestic politics and foreign policy priorities can influence an African country's relations with the world second great power and econo- 
AFRICAN

AFFAIRS

my. Having said that, much wealthier [US\$ 10,000 Gross Domestic Product (GDP)/per capita] and less populated (1.67 million) than other African nations and enjoying more options than many of them, Gabon may remain a special case.

This article is based on fieldwork and interviews conducted in Gabon in January 2014 as well as published first-hand and second-hand materials. It aims at holistically analysing the more recent dynamic of Gabon-China relations and the place it occupies in Gabon's diplomacy and economic development strategy.

\section{Background of Gabon-China relations}

After the establishment of diplomatic relations between Gabon and China in 1974, relations between both countries remained for a long time driven more by political

\section{Map 1: Gabon with major cities and neighbouring countries}

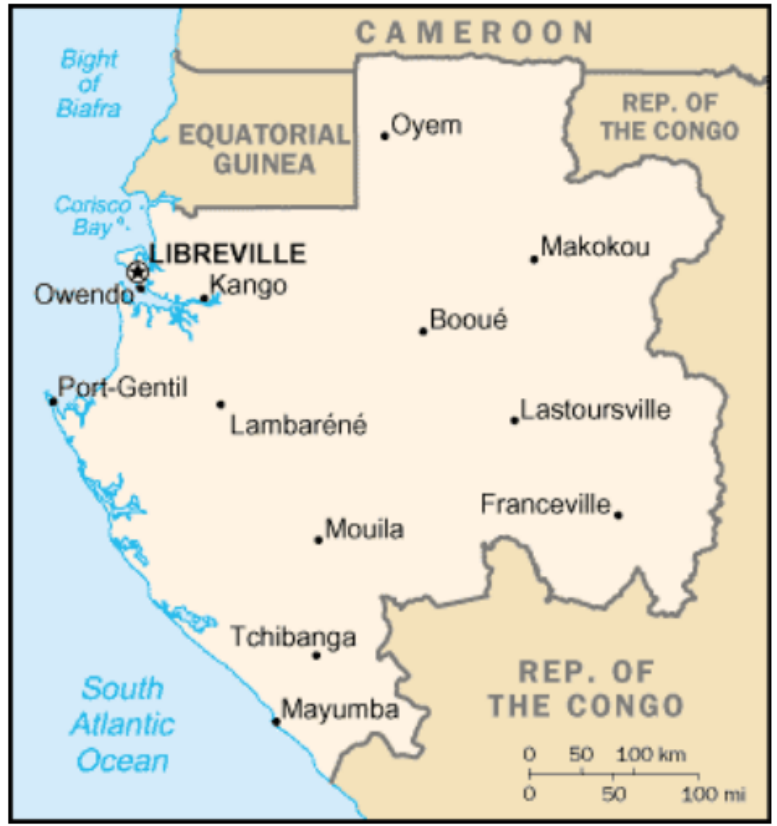

(C) Centre for Chinese Studies, Stellenbosch University 
rather than economic considerations. Although Omar Bongo visited China eleven times (in 35 years), trade was limited and the Chinese presence in Gabon was restricted to a handful of symbolic infrastructure projects, such as the National Assembly, built in 2002. The real turning point took place in 2004 when President Hu Jintao visited Gabon.

\section{The 2004 turning point}

After 2004, the Chinese authorities continued to deliver turnkey iconic buildings as the Stade de l'Amitié sino-gabonaise (Sino-Gabonese Friendship Stadium), completed right on time for the 2012 Coupe d'Afrique des Nations (African Cup of Nations). But at the same time they started to get more interested in the extraction of Gabon's rich natural resources, particularly oil, timber and iron ore, and involved in its economic development plan. Two large deals were signed, the first one to guarantee a minimum supply of crude oil to China, the second one between Unipec, a subsidiary of Sinopec, and Total Gabon for oil exploration and refining in Gabon. While remaining modest, Chinese oil imports from Gabon increased to nearly US\$1 billion in 2009.

In the extractive industries sector, China's interest for the untapped iron ore mine of Bélinga became obvious when in 2005 a consortium led by CMEC (China National Machinery and Equipment Import and Export Corporation) and financially supported by the Eximbank, displaced the one led by Companhia Vale do Rio Doce (CVRD, better known as Vale) from Brazil and was granted, a year later, the sole rights to develop this mining complex (Yates, 2008:216-220). We will discuss the Bélinga saga below, but suffice is to indicate here that the Chinese offer, a package deal of US\$3 billion, was highly attractive, including the construction of two dams, a new railway line $(560 \mathrm{~km})$ all the way to Santa Clara and a new harbour in the coastal city located north of Libreville.

At the same time, China having become a large importer of manganese (including from Gabon), two Chinese companies decided to join forces to try to get into the extraction business of this mineral. After having set up a Sino-Gabonese jointventure called Compagnie industrielle et commerciale des mines de Huazhou 
(CICMH or Huazhou Industrial and Commercial Mining Company), this company received a license in 2007 to prospect and exploit manganese in the M'Bembélé Mountains, 36 kilometres $(\mathrm{km})$ from Ndjole, a city located on the Transgabonais railway $150 \mathrm{~km}$ east of Libreville, and build a port next to COMILOG's in Owendo, south of the capital (Jansson et al., 2009:18). The Chinese investment amounted to US\$ 420 million to US\$ 560 million, including a US\$ 84 million loan provided by its main shareholder, Huazhou Mining Investment Company at an interest rate of 6.5 per cent ${ }^{1}$.

In the infrastructure sector, China intensified its presence with the signing in 2008 of an agreement for the building of the Grand Poubara dam $15 \mathrm{~km}$ outside of Franceville in the province of Haut-Ogooué, more than $700 \mathrm{~km}$ southwest of Libreville, an area where the Compagnie minière de l'Ogooué's (COMILOG) main manganese mine is located. Built in 56 months by PowerChina, a subsidiary of Sinohydro under an engineering-procurement-construction basis, this dam started to operate in September 2013. Financed by a concessional loan of US\$ 83 million to be reimbursed over 20 years at a 3 per cent interest rate with a grace period of 7 years, this dam will have a $160 \mathrm{MW}$ capacity when in full operation (Alves, 2008:10; Interview 2, January 2014) 2 .

Although it would be an exaggeration to qualify the strengthening of the Libreville -Beijing relations after 2004 as an "axis", on both sides there was a clear willingness to give more economic substance to their political partnership (Dittgen, 2011b: 8).

\section{From Omar to Ali Bongo: the limits of the Sino-Gabonese rapprochement}

It is clear that already under Omar Bongo, the Gabonese authorities did not want to become too dependent upon China. Then Foreign Minister Jean Ping, although of Chinese descent, was himself candid about the fact that, in his view, China would never replace France (Centre for Chinese Studies, 2007:75). Nevertheless, after Ali Bongo succeeded his father, Gabon readjusted its relations with China and decided to set limits to its partnership with China and its role in Gabon's development plan (Interviews 1, 3, 4, 5 and 12, January 2014). Or to be more accu- 
rate, Ali Bongo has used his connections in the United States, actually more so than in France, to balance as well as better scrutinise Chinese companies' activities in Gabon. For instance, in 2010, he set up a National Infrastructure Agency (Agence Nationale des Grands Travaux or ANGT). Its role is to identify, plan, manage and implement all major public infrastructure projects. He asked the US (Californian) engineering corporation, Bechtel, to provide ANGT with technical expertise and supervise them. Equipped with a very cosmopolitan staff of 350 and a budget of US\$ 200 million, Bechtel has strengthened Ali Bongo's supervision of all the important "priority projects" (180 identified, 90 selected) and contributed to introducing more transparency and accountability as well as to limiting waste, corruption and kickbacks (Interview 2, January 2014).

That does not mean that Sino-Gabonese relations have become colder. High-level political contacts have continued to be quite regular and warm. In the Spring of 2010, President Ali Bongo travelled to China on the occasion of the opening of the World Expo in Shanghai, an exhibition that his Prime Minister, Paul Biyoghe Mba visited in July of the same year ${ }^{3}$. But the rhythm of official visits, especially at the presidential level seems to have slowed down and the whole relationship has become less warm and more pragmatic.

\section{Economic relations: trade and investments}

\section{Bilateral trade}

While since 2008 China has become Gabon's second largest client ahead of France (with the USA as the largest), it has remained its third largest trade partner, because Gabon still imports a lot of goods, especially food products, from its former colonial master.

After rapid progression in the 2000s in trade volumes, China accounted for a 7.2 per cent ( 7.9 per cent according to Chinese statistics) share of Gabon's total volume of merchandise trade by 2012. China was still clearly behind the USA (44.8 per cent) and the European Union as a whole (31 per cent), but closing up with France (9.1 per cent) (Table 1). Gabon continues to export most of its products, 
AFRICAN

especially oil and mineral products, to the USA (59 per cent) and the EU (18 per cent) while only 8 per cent go to China and 2.3 per cent to France (cf. Table 2).

In terms of imports, Gabon buys most of the goods it needs from Europe (65 per cent) and particularly France (27.2 per cent). Whilst driven by an increasing number of Chinese projects, purchases from China are probably higher than local statistics indicate (cf. Table 1). Officially they do not represent more than 12 per cent of Gabon's total imports. ${ }^{5}$. The major imported items from China are mechanical and electrical appliances, construction materials and machinery. Moreover, since 2003, bilateral trade progression between China and Gabon has been fast but irregular, affected by the financial crisis and, after 2010, the export ban imposed on unprocessed wood; since then manganese rather than oil and timber production have

Table 1: Comparison of Gabon's total trade volumes with China, 2003 - 2012 (Million US Dollars)

\begin{tabular}{|c|c|c|c|c|c|c|c|c|c|}
\hline \multirow{2}{*}{ Year } & \multicolumn{3}{|c|}{ China } & \multicolumn{3}{c|}{ WTO } & \multicolumn{3}{c|}{ UN } \\
\cline { 2 - 11 } & Exports & Imports & Total & Exports & Imports & Total & Exports & Imports & Total \\
\hline 2003 & 301 & 9 & 310 & - & - & - & - & - & - \\
\hline 2004 & 400 & 14 & 414 & - & - & - & 175 & 15 & 190 \\
\hline 2005 & 352 & 41 & 393 & 310 & - & 310 & 203 & 25 & 228 \\
\hline 2006 & 817 & 64 & 881 & 594 & 45 & 639 & 636 & 45 & 681 \\
\hline 2007 & 1,095 & 103 & 1,198 & 652 & 59 & 710 & 600 & 83 & 682 \\
\hline 2008 & 1,793 & 138 & 1,931 & 922 & 64 & 986 & 1,260 & 101 & 1,361 \\
\hline 2009 & 719 & 155 & 873 & 541 & 57 & 598 & 428 & 122 & 550 \\
\hline 2010 & 967 & 206 & 1,173 & 750 & 146 & 896 & - & - & - \\
\hline 2011 & 576 & 270 & 846 & 960 & 186 & 1,146 & - & - & - \\
\hline 2012 & 618 & 427 & 1,045 & 773 & 178 & 951 & - & - & - \\
\hline
\end{tabular}

Sources: China Commerce Yearbook 2013, China Commerce and Trade Press; UN Comtrade Database, 2013; World Trade Organization Trade Profiles, from 2006 to 2013. 
spurred Gabon's exports to China, which buys 25 per cent of Gabon's manganese production. Conversely, as $15^{\text {th }}$ African exporter to China and $32^{\text {nd }}$ African importer from China in 2012, Gabon is not one of China's key trade partners in Africa (China Commerce Yearbook, 2013: 72-74).

Table 2: Gabon's merchandise trade with selective partners (Million US Dollars) 4

\begin{tabular}{|c|c|c|c|c|c|c|c|}
\hline \multirow{5}{*}{$\begin{array}{c}\text { By } \\
\text { Destination / } \\
\text { Origin }\end{array}$} & Gabon's Merchandise Trade & \multicolumn{2}{|c|}{2005} & \multicolumn{2}{|c|}{2008} & \multicolumn{2}{|c|}{2012} \\
\hline & Total Volumes & \multicolumn{2}{|c|}{6,313} & \multicolumn{2}{|c|}{11,150} & \multicolumn{2}{|c|}{13,296} \\
\hline & Total Exports & \multicolumn{2}{|c|}{4,920} & \multicolumn{2}{|c|}{8,700} & \multicolumn{2}{|c|}{9,665} \\
\hline & Total Imports & \multicolumn{2}{|c|}{1,393} & \multicolumn{2}{|c|}{2,450} & \multicolumn{2}{|c|}{3,631} \\
\hline & Balance & \multicolumn{2}{|c|}{3,527} & \multicolumn{2}{|c|}{6,250} & \multicolumn{2}{|c|}{6,034} \\
\hline \multirow[t]{4}{*}{ US } & Total (\% of total volumes) & 2,475 & $39.2 \%$ & 5,260 & $47.2 \%$ & 5,960 & $44.8 \%$ \\
\hline & Exports (\% of total exports) & 2,411 & $49 \%$ & 5,081 & $58.4 \%$ & 5,702 & $59.0 \%$ \\
\hline & Imports (\% of total imports) & 64 & $4.6 \%$ & 179 & $7.3 \%$ & 258 & $7.1 \%$ \\
\hline & Balance & \multicolumn{2}{|l|}{2,347} & \multicolumn{2}{|l|}{4,902} & \multicolumn{2}{|l|}{5,444} \\
\hline \multirow[t]{4}{*}{$\mathbf{E U}$} & Total (\% of total volumes) & 1,629 & $25.8 \%$ & 2,692 & $24.1 \%$ & 4,094 & $30.8 \%$ \\
\hline & Exports (\% of total exports) & 679 & $13.8 \%$ & 1,053 & $12.1 \%$ & 1,730 & $17.9 \%$ \\
\hline & Imports (\% of total imports) & 950 & $68.2 \%$ & 1,639 & $66.9 \%$ & 2,364 & $65.1 \%$ \\
\hline & Balance & \multicolumn{2}{|l|}{-271} & \multicolumn{2}{|l|}{-586} & \multicolumn{2}{|l|}{-634} \\
\hline \multirow[t]{4}{*}{ China } & Total (\% of total volumes) & $/$ & $/$ & 986 & $8.8 \%$ & 951 & $7.2 \%$ \\
\hline & Exports (\% of total exports) & 310 & $6.3 \%$ & 922 & $10.6 \%$ & 773 & $8.0 \%$ \\
\hline & Imports (\% of total imports) & 1 & / & 64 & $2.6 \%$ & 178 & $4.9 \%$ \\
\hline & Balance & \multicolumn{2}{|l|}{ / } & \multicolumn{2}{|l|}{858} & \multicolumn{2}{|l|}{595} \\
\hline \multirow[t]{4}{*}{ France } & Total (\% of total volumes) & 804 & $12.7 \%$ & 1,482 & $13.3 \%$ & 1,210 & $9.1 \%$ \\
\hline & Exports (\% of total exports) & 234 & $4.8 \%$ & 574 & $6.6 \%$ & 221 & $2.3 \%$ \\
\hline & Imports (\% of total imports) & 570 & $40.9 \%$ & 908 & $37.1 \%$ & 989 & $27.2 \%$ \\
\hline & Balance & \multicolumn{2}{|l|}{-336} & \multicolumn{2}{|l|}{-334} & \multicolumn{2}{|l|}{-768} \\
\hline
\end{tabular}

Sources: OECD Stat, 2014; China Commerce Yearbook 2013, China Commerce and Trade Press; UN

Comtrade Database, 2013; World Trade Organization Trade Profiles, from 2006 to 2013. 
AFRICAN

AFFAIRS

\section{Chinese investments in Gabon}

Since 2004, China has been involved in a growing number of projects. However, its direct investments in Gabon have remained rather small, its stock amounting to US\$128 million in 2012 or 3 per cent of the overall FDI in Gabon: close to the US level of 3.7 per cent. It has also remained far behind France at 41.7 per cent (Table $3)$. And while the export ban of unprocessed wood was probably responsible for the 2011 drop, the FDI inflow trend has not yet shown a clear increase in China's share which was at 4.4 per cent in 2012 (Table 4).

Among the recent Chinese investments, it is worth mentioning the acquisition in July 2012 by Golden Millennium Group (GMG), a Singapore-based subsidiary of SINOCHEM, of 35 per cent shares of the Belgium holding SIAT (Société d'Inves-

Table 3: Distribution of Gabon's FDI inward stock, 2003-2012 (Million US Dollars)

\begin{tabular}{|c|c|c|c|c|}
\hline \multirow{2}{*}{ Year } & Total FDI & \multicolumn{3}{|c|}{ Partner Country } \\
\cline { 3 - 5 } & Inward Stock & France & US & China \\
\hline $\mathbf{2 0 0 3}$ & -73 & 1,782 & 370 & 24 \\
\hline $\mathbf{2 0 0 4}$ & 246 & 2,163 & 483 & 31 \\
\hline $\mathbf{2 0 0 5}$ & 488 & 2,219 & 121 & 35 \\
\hline $\mathbf{2 0 0 6}$ & 756 & 2,638 & 113 & 51 \\
\hline $\mathbf{2 0 0 7}$ & 1,026 & 2,856 & 249 & 56 \\
\hline $\mathbf{2 0 0 8}$ & 1,799 & 1,482 & -87 & 88 \\
\hline $\mathbf{2 0 0 9}$ & 2,372 & 1,944 & -78 & 100 \\
\hline $\mathbf{2 0 1 0}$ & 2,871 & 1,935 & 586 & 125 \\
\hline $\mathbf{2 0 1 1}$ & 3,567 & 1,731 & 63 & 127 \\
\hline $\mathbf{2 0 1 2}$ & 4,269 & 1,780 & 157 & 128 \\
\hline
\end{tabular}

Sources: OECD Stat, 2014; China Commerce Yearbook 2013, China Commerce and Trade Press; UN Comtrade Database, 2013; World Trade Organization Trade Profiles, from 2006 to 2013. 
Table 4: Distribution of Gabon's FDI Inflows, 2003-2012 (Million US Dollars)

Table 4: Distribution of Gabon's FDI Inflows, 2003-2012 (Million US Dollars)

\begin{tabular}{|c|c|c|c|c|}
\hline \multirow{2}{*}{ Year } & \multirow{2}{*}{$\begin{array}{c}\text { Total FDI } \\
\text { Inflows }\end{array}$} & \multicolumn{3}{|c|}{ Partner country } \\
\cline { 2 - 5 } & 206 & France & US & China \\
\hline $\mathbf{2 0 0 3}$ & 320 & -33 & 11 & \\
\hline $\mathbf{2 0 0 4}$ & 242 & 42 & 61 & 6 \\
\hline $\mathbf{2 0 0 5}$ & 268 & 138 & -166 & 2 \\
\hline $\mathbf{2 0 0 6}$ & 269 & 158 & -17 & 3 \\
\hline $\mathbf{2 0 0 7}$ & 773 & 275 & 130 & 32 \\
\hline $\mathbf{2 0 0 8}$ & 573 & 382 & -439 & 23 \\
\hline $\mathbf{2 0 0 9}$ & 499 & 54 & 4 & 2 \\
\hline $\mathbf{2 0 1 0}$ & 696 & -8 & 327 & 31 \\
\hline $\mathbf{2 0 1 1}$ & 702 & 26 & 94 & 78 \\
\hline $\mathbf{2 0 1 2}$ & 207 & & 23 \\
\hline
\end{tabular}

Sources: OECD Stat, 2014; China Commerce Yearbook 2013, China Commerce and Trade Press; UN Comtrade Database, 2013; World Trade Organization Trade Profiles, from 2006 to 2013.

tissement pour l'Agriculture Tropicale or Tropical Agriculture Investment Company). SIAT's subsidiary, SIAT Gabon, created in 2004, is Gabon's leading producer of palm oil and natural rubber (SIAT 2012). SIAT Gabon is active in three provinces (Moyen Ogooué, Estuaire and Woleu-Ntem) and produces among other things cooking oil and soaps. SIAT is also active in Nigeria and Ghana in the same sectors while GMG is already present in Cameroon and Cote d'Ivoire (Ballong, 2012). Presented as a "strategic alliance", this investment may be indicative of a stronger Chinese willingness to be more active in the Gabonese agro-industrial sector (SIAT Gabon). In Gabon, SIAT's main competitor is Olam, an Indian group based in Singapore, whose production areas include timber, rubber, palm oil and fertilisers. In January 2014, Olam sold a large part of its forestry and saw milling assets to a consortium of Chinese investors, for US\$ 18 million (Chan, 2014). All in all, while Gabon is not a privileged destination for Chinese FDIs in Africa, in view of its small population, it is hard to argue that it has been neglected either. 
AFRICAN

AFFAIRS

\section{China's infrastructure projects in Gabon}

Apart from the projects already mentioned as the Poubara Dam, China has been involved in a growing number of infrastructure projects, especially the construction of roads and the iconic Port Mode in Libreville. Both types of project have a strong political dimension.

In September 2013, the China Road and Bridge Company signed a contract to build the road from Port-Gentil to Libreville via Omboué and then Lambarene. Planned over a period of four years, this ambitious and difficult project (it crosses a very swampy region) will for the first time link up Gabon's second city and the heart of its oil production to its capital. Today one can only reach Port-Gentil, located on the Mandji island, from Libreville by boat or by plane. This project will cost 341.837 billion CFA (US\$ 723 million), mainly financed by China's Eximbank (95 per cent) and symbolically by the Gabonese government ( 5 per cent).

The construction of the first section (Port-Gentil-Omboué, $93 \mathrm{~km}$ ) was started in November 2013, with Gabon having received a concessional loan from China of 64.8 billion CFA (US\$ 137 million) to finance it ${ }^{6}$. The extension from Omboué to Yombi $(243 \mathrm{~km})$ will eventually allow this road to link up with the Nationale No. 1, Gabon's main road from Libreville to the south of the country (Lambaréné, Ndendé) and Congo-Brazzaville. It has been reported that this big construction project will create 2,000 jobs for the Gabonese and 800 for the Chinese (Ogandaga, 2013).

The road project has clear political implications since the region of Port-Gentil was for a long time an opposition stronghold to Omar Bongo. For instance, some violence took place there against electoral fraud in 2009 (the French consulate was burnt down). Although since then, the ruling Parti Démocratique Gabonais (PDG) has been able to have its candidate elected mayor of the city, Ali Bongo is clearly trying to reach out to Ogooué's Maritime voters, with the help of Chinese money.

The Port Môle project in Libreville is an interesting case of Chinese opaque cooperation serving obvious political purpose as well. Announced on the occasion of 
the "New York Forum Africa" in June 2013 ${ }^{7}$, Port Môle is an ambitious project that will create a window of "emerging Gabon" on reclaimed land located outside of the Boulevard de l'Indépendance, the capital's main (and often congested) north -south road along the seaside, and in front of the Boulevard Triomphal that leads to the ministries and the National Assembly. The project will include commercial, cultural and conference centres, a museum, hotels, offices and a cruise terminal. It is supposed to become the new heart of Libreville. The overall budget of this project amounts to US\$ 450 million; signed in May 2012 with the China Harbour Engineering Company (CHEC) for maritime infrastructure. The contract includes the creation, in 360 days, of a reclaimed peninsula of 43 hectares and should cost US $\$ 120$ million, reimbursed over 20 years, probably with a grace period that was however not made public (ANGT, 2013; Chine-Gabon, 2013).

Officially a tender was organised, but no one in the construction industry saw the actual tender (Interview 2, January 2014). It appears that the Chinese company was handpicked by the president because of the urgency of the project; it must be finished in 2015, or one year before the next presidential election. For the same reasons, the Gabonese government has allowed the Chinese contractor to rely to a large extent on a Chinese workforce and has not been very vigilant about the consequences for the Libreville estuary of CHEC's dredging operations (Interview 2, January 2014).

\section{Other Chinese economic inroads}

Chinese companies have made some inroads into other economic sectors like the telecoms where Huawei and ZTE's arrivals have been seen as the main drivers for French giant Alcatel's departure. However, the local market remains dominated by other actors: Gabon Telecom is owned by Maroc (Morocco) Telecom while the main operator is Airtel, controlled by an Indian company. And there have been cases of co-operation between Chinese and Western companies in this sector (for example between Huawei and French company Bouygues for the installation of backbone optic fibres). In other words, this sector has remained very open and diverse (Interviews 2 and 6, January 2014). 


\section{AFRICAN \\ EAST-ASIAN \\ AFFAIRS

In the wholesale distribution and supermarket sectors, more Chinese merchants now compete with the well-established French companies (for instance Casino) or Lebanese traders. Chinese merchants are sometimes accused of not respecting the customs legislation but similar criticism has been made against other operators, especially the Lebanese.

Chinese presence in the fishing industry must be indicated since it has created some frictions with the local authorities and fishermen, for instance in Mayumba (Gabon: Pêche Sauvage, 2012). A growing number of Chinese fishing boats even fish for Gabonese companies and market. Although legally forbidden, the Gabonese ministry of Agriculture and Fisheries seems to tolerate this practice and has been accused by some of our interviewees of corruption. In the last few years, Chinese boats have focused on shrimp fishing with an intensity that has alarmed the Gabonese presidency which wanted to ban shrimp fishing altogether in early 2014. In any event, with the help of the EU and on the basis of conventions concluded between the EU and Gabon, French and Spanish tuna fishing boats have been asked to exert a surveillance of fishing activities in Gabon and report illegal fishing. This measure is understood as mainly targeting Chinese fishing boats (Interview 4, January 2014).

In the service sector, it is worth mentioning the successful emergence of the Chinese company "Groupe l'Etoile d'or" which has built and is managing several mid -range hotels (three stars) in Libreville, especially in the districts of La Sablière, Louis, London, Quaben and Montagne Sainte. Filling up an underdeveloped market niche, these hotels are popular not only among Chinese delegations but a growing number of foreign visitors who cannot afford the often overpriced and illmanaged five stars hotels of the capital.

The development of Sino-Gabonese co-operation since the mid-2000s has also led to the opening of a growing number of Chinese restaurants and shops, particularly in the animated district of Louis.

\section{A small but dynamic Chinese community}

The Chinese community in Gabon is still very small but dynamic and growing. As 
usual, estimations vary. For the Chinese embassy (Interview 5, January 2014), their number is around 2000 to 3,000, not much more than in 2007 (Centre for Chinese Studies, 2007: 89). While the vox populi gives figures ten times larger (20,000 to 30,000). More cautious sources indicate that they are 6,000 Chinese nationals, probably half of them not registered, concurring with the official data (Interview 3, January 2014). Most Chinese $(2,000)$ work on projects and are not destined to stay permanently in Gabon while long-term Chinese resident do not number more than 1,000 (Interview 5, January 2014).

The local Association of Overseas Chinese in Gabon includes only 2,000 members and the number of Chinese businesses in Libreville is estimated at 20-30. The Gabonese authorities do not see Chinese immigration as an issue as it has remained very difficult for Chinese migrants or contractual workers who wish to stay behind to get a residence permit. The powerful Direction générale de la Documentation et de l'Immigration (General Office of Documentation and Immigration) of the Ministry of Interior is very restrictive and appears much harder to be bribed than its counterparts in the neighbouring countries (Interview 2, January 2014).

\section{Other areas of co-operation}

\section{Educational co-operation}

The education co-operation between China and Gabon has remained largely symbolic. The number of scholarships for Gabonese students to study in China is still fairly low - with about 40 scholarships per year (Interview 5, January 2014), although it has increased since 2010. The total number of Gabonese students in China was 215 in 2008 and probably around 300 in 2012.

Today, most Gabonese students continue to study in France. In 2010, 4,205 of the 5,793 Gabonese students in "international mobility" went to France (73 per cent) ${ }^{8}$. In addition, there have been some talks since 2006 about the opening of a Confucius Institute at the Omar Bongo University in Libreville but in 2014, it was not yet open, for unknown reasons, underscoring a lack of enthusiasm on the Gabonese side. One should add to this the fact that most Gabonese from well-off fami- 
lies do not go to the university in their own country but overseas, mainly in France but also increasingly in the USA. Moreover, Ali Bongo's priority is not Chinese but English which in 2012 became Gabon's second official language, underscoring a willingness not only to develop closer relations with the USA but also to enhance regional integration with Anglophone neighbours.

\section{Military exchanges}

Here again, owing to the Gabonese armed forces' very close relationship with France and the presence of a permanent French military base near Libreville (1,600 marines), it has been hard for China to develop a meaningful military cooperation with Gabon. Military exchanges between Libreville and Beijing have remained very secretive, carefully but discreetly observed both by Paris and Washington. Yet, in 2007, a military attaché joined the Chinese embassy, underlining the growing strategic importance for China of Gabon as far as Central Africa's regional security is concerned, both because of the presence of France's major permanent military basis in Central Africa but also the USA's interest in Gabon. Around 2008, there apparently were speculations about the opening of an Africom base in Gabon (Wikileaks, 2008). The involvement of French troops stationed in Libreville in the stabilisation of the Central African Republic (CAR) in 2013-2014 has confirmed the usefulness for China or any great power to have a military intelligence officer there. It can be added that, due to its stability, the Chinese government has chosen Gabon as a gathering place, if the outbreak of trouble or violence in CAR, Cameroon or elsewhere requires the evacuation of its nationals from Central Africa.

For these reasons probably, military exchanges between Gabon and China have increased in the last few years. In June 2009, both armies conducted a joint humanitarian medical urgency exercise, the first of this kind organized with an African military (PLA Daily, 2009). In October 2011, Gabon's Defence Minister Bokemu Ongzongka visited China and in June 2012, the PLA deputy chief of staff Sun Jianguo visited Gabon (Ambassade de la République populaire de Chine au Gabon, 2012). Although these exchanges and visits are part of what China calls its 
"military diplomacy", they have allowed some Gabonese officers to be invited for a few months to the National Defence University in Beijing and may convince Libreville, in spite of French objections, to buy a limited number of cheaper military equipment (such as transportation vehicles) from Beijing in the future.

\section{Limits of China's presence in Gabon}

However, China's presence and influence in Gabon has witnessed several hurdles. First, some of its companies and industrial projects, particularly Addax and Bélinga, have failed. Secondly, the Gabonese government and society have accumulated a number of grievances that, while not very different from elsewhere in Africa, underscore the difficulties and slowness of Chinese authorities, and more particularly, companies' adjustments.

\section{The Addax affair}

China had earlier encountered some difficulties in Gabon's oil industry. In 2006, Unipec, a subsidiary of Sinopec, was accused by local NGOs and the World Bank of exploring oil in the Loango National Park, damaging the environment, especially the forest of this protected area. However, most analysts agreed that the responsibility of the dispute around this exploration block (called the Lotus block) was shared by the Chinese company, which had committed obvious negligence, cutting down many trees, and the Gabonese government which had given Unipec the right to explore oil in Gabon. The failure on Gabon's side was the result of a lack of coordination between the Oil Ministry and the Forestry and Environment Ministry of Gabon (Centre for Chinese studies, 2007: 95-96). In spite of the bad image that it created, particularly among Gabonese NGO activists, a settlement was reached after a few months of negotiations between Unipec and the Gabonese government (Alves, 2008:15-16).

The Addax affair which broke out in late 2012 was more serious. Initially a Canadian firm, then Americo-Swiss and Addax Petroleum was finally acquired by Sinopec in 2009. After this acquisition Addax Petroleum was accused by the Gabonese government of bad management, damage to the environment, corruption and 
tax evasion and more generally having failed to fulfil its contractual obligations. As a result, Addax lost the right to exploit one of five fields it had in Gabon, the Obangue field, transferring it to the newly created state-owned Gabon Oil Company (GOC). Negotiations having failed, Sinopec decided to sue the Gabonese government before the Paris-based international Chamber of Commerce's arbitration court but lost its case in September 2013 (Farge, 2013). Negotiations have been held since then and a new ten-year production sharing contract was signed by Addax and the Gabonese Republic in January 2014, but only on three fields, including Obangue (Addax, 2014). It was later revealed that Addax paid US\$ 400 million in compensation to the Gabonese Oil Ministry, under Etienne Ngoubo, due to an estimated loss to Gabon of US\$ 1 billion (Agence Ecofin, 2014). How had this happened?

China is not a big player in the Gabonese oil industry. But by acquiring Addax in 2009, Sinopec wished to enter the country's oil producers club. In 2012, Addax was Gabon's fourth largest oil producer (23,000 barrels per day) far behind Shell (64,000 b/d), Total (57,000 b/d) and Perenco (55,000 b/d). In oil exploration, China is not a major actor either, only two of the ten companies involved are Chinese: Sino Gabon Oil and Gas and Sinopec Overseas (Trésor, 2012) ${ }^{9}$.

With regard to the dispute, the official reasons for calling the dispute as presented by the Gabonese government are only part of the truth. Environmental degradation had been evidenced by outside witnesses before and Addax was openly threatened with having one of its remaining fields closed "if the situation did not improve". However, the main accusation was tax evasion. Addax was targeted for having reported underestimated production results, as a result avoiding paying some US\$ 400 million of royalties to the Gabonese treasury (Interview 2, January 2014). This discovery was the consequence of an audit of all oil companies launched by the Gabonese president with the help of an US audit firm in 2011-2012 (Farge, 2013). All companies, including Total and Shell, were criticised and asked to make some adjustment but Addax was singled out because of the magnitude of its fraud and the multiplicity of its bad practices. Of course, some observers have noticed that it was hard for the Gabonese government to be too harsh towards companies in 
which it has a share ( 30 per cent in Total, less in Shell). But, this audit has been part of Ali Bongo's policy of enhancing accountability in the oil industry and did not particularly target China (Interviews 2 and 7, January 2014).

Having said that, the Addax affair revealed two trends: 1) the tendency of big Chinese state-owned companies operating in Africa to take more liberty with the rules of the game than their competitors, not only in the oil business; 2) the increasing vigilance of the Gabonese government and its inclination to use US firms and experts to help them in correcting bad practices.

\section{The Bélinga fiasco}

China's second major setback in Gabon was the decision made by the Gabonese government in December 2013 to cancel the license that had been given to COMIBEL to exploit the Bélinga iron ore mine. COMIBEL (Compagnie minière de Bélinga), in which the CMEC held 75 per cent of the shares after 2007, was reimbursed US\$ 34 million for the feasibility study that it had completed but the mine was again open to any company willing to invest in the costly but potentially highly profitable project.

Omar Bongo had invested a lot of political capital, and calculation in this project. He also expected a lot of returns in terms of modernisation and job creation from the CMEC deal, hoping to turn Bélinga into Gabon's second city (Yates 2008: 218). China's expectations were not smaller; Bélinga then being presented as its "crown jewel" in Gabon, and part of a larger plan to enhance not only its economic but also political influence in Gabon (Alves, 2008: 20; Dittgen, 2011a: 11). So why did it fail?

As usual, many factors played a role in this fiasco but three were clearly more influential (Interviews 2, 4, 5, 9, January 2014): 1) CMEC's inability to pilot and coordinate such an ambitious and complicated infrastructure-for-minerals-barter deal; 2) the increasing criticism of the Gabonese NGOs and the slowness of the environmental studies; and lastly 3) Omar Bongo's death and his son's decision to take advantage of the difficulties encountered by COMIBEL to change horse be- 


\section{AFRICAN \\ EAST-ASIAN \\ AFFAIRS \\ THE CHINA MONITOR}

fore it was too late. The volatility of iron ore prices may have also made the CMEC hesitant (Dittgen, 2011b: 14) but that was not presented as a decisive reason for freezing the project.

Bélinga is one of the largest untapped iron ore deposits ( 1 billion tons, for an iron ore purity of 60 per cent) in the world and stretches across Gabon, Cameroon and Congo Brazzaville territories (Trésor, 2013). However its remote location and the much needed infrastructure to be built for its exploitation (dams or other sources of electricity, railroads, and harbour) kept any project plans limited in terms of cost until demand and prices of the raw mineral began increasing in the 2000s.

The Chinese had submitted a very comprehensive and self-financed US\$ 3 billion offer. This offer included the construction of a $560 \mathrm{~km}$ new railway line in two sections (Belinga to Booue and Ntoum to Santa Clara, a port north of Libreville) due to be completed in 2009, the construction of two hydroelectric dams on the Ivindo river, including the Bélinga Dam (50 MW, cost: US\$ 754 million), and of an iron mining facility (construction cost: US\$ 790 million). It also included the creation of a deep-water mining harbour in Santa Clara that can manage 20 million tons of exports, for which the feasibility study was concluded in December 2008 (Banktrack, 2011). The construction of these infrastructure projects was supposed to start in 2008 and be complete in 2011, when the mine was due to become operational and the first shipments of iron ore to China could take place. It was then also indicated that the CMEC had "carefully chosen partners", including the Eximbank, the Panzihua Iron and Steel Company Mines, China Railway Engineer Corporation (CREC) and the China Harbor Engineer Company Ltd., a subsidiary of China Communication and Construction Company. 30,000 new jobs were due to be created including 26,000 for Gabonese citizens; training, including in China for Gabonese engineers and technicians was to be organised and the construction in Bélinga of a Steel City (cité métallurgique) was also projected. 30 million tons of iron ore per year, 90 per cent for China, was expected to be produced (International Rivers, no date).

It is hard to identify a more ambitious project, and its complexity has been often underestimated, both by the Gabonese government and the China-led consortium. 
Actually, Chinese companies are more and more reluctant to get involved, let alone lead multi-dimensional projects of such a grand scale (Interviews 5 and 10, January 2014). As its name indicates, the CMEC's main activity is trading heavy machineries and equipment, not mining nor dam, railways or harbour construction. The financing was not an issue, at least for China, as the concessional model proposed was to repay the investment with the production of the mine over a 25-year period of time (Jansson, 2009: 24). But COMIBEL's main shareholder did not have the expertise required to properly assess the magnitude of the projects and forecast the resistances that it would provoke within the Gabonese society (Interviews 2, 5 and 12, January 2014).

That brings us to the second reason of failure: the mobilisation of environmental protection NGOs against not so much the exploitation of the mine itself than the lack of benefits for the local population and the construction of a dam on the Ivindo river in the heart of Gabon's forest and national park. Among them, Brainforest, an ONG directed by Marc Ona Essangui and supported by Rainforest United Kingdom, played a leading role, proposing among other things to move the construction of the dam from the Kongou Falls to the Tsengué-Lélédi Falls, a site that was recommended by a feasibility study in the 1960s for its cost-effectiveness and greater potential benefits to local communities (Rainforest, 2009; Openshaw, 2012). Pressure was also exerted by Gabonese NGOs on their government so that it gets more involved in a project that was perceived by them as too secretive, not environmentally sustainable and that would give CMEC much more land that it needed. As a result of this lobbying, the Gabonese government's shares in the COMIBEL increased from 15 per cent to 25 per cent in December 2007.

These developments together with the global economic downturn in 2008 clearly slowed down the project and affected the CMEC's enthusiasm, pushing back any start of the exploration activities to a later date (it was initially planned to be completed by 2012). Eventually, in 2009, the Chinese operators delivered feasibility and environmental impact assessment (EIA) studies; ambassador Xue Jinwei intervening to accelerate the process. And it was reported that exploration activities were about to start when Omar Bongo died (Jansson, 2009:40). 
In any event, it rapidly appeared that this project had much less support from his son, Ali Bongo (Interviews 7, 8 and 9, January 2014). Both for electoral and diplomatic reasons Omar Bongo was ready to give China a preferential treatment and to disregard the overall cost of the project. The large interest-free or preferential loans offered by Eximbank were indeed attractive (Dittgen, 2011b:15). However, the Gabonese government had also to face growing criticism for the tax benefits enjoyed by COMIBEL, the long period of reimbursement of the Chinese loan (25 years) and the high risks attached to it, due to the fluctuations of iron ore prices and the uncertainties about the Bélinga iron ore reserves. Indeed, China's interests were very well protected in the contract, including an additional clause requiring other possible methods of compensation from the Gabonese government, should the Bélinga iron ore reserve be insufficient to reimburse the loan (Dittgen, 2011b:21). Moreover, questions were raised about the maintenance and utility of infrastructure after 25 years of operation and the fact that production was to be mainly sold to China. Finally, the overall price tag of the project was not US\$3 billion but US\$10 billion according to well-informed sources, putting on Gabon's shoulder a financial burden that would have fed its external debt and it would have difficulties to reimburse (Trésor, 2013). In other words, the Chinese package turned out to be much less attractive than it had initially appeared (Jansson, 2010).

Diplomatic considerations have also contributed to the Gabonese government's decision to cancel the concession. Closely scrutinised by the ANGT, the CMEC's difficulties gave Gabon the occasion to decrease its reliance on China for its development (Interviews 2 and 5, January 2014). While the Sino-Gabonese relationship does not seem to have been deeply affected by this cancelation, it had been Beijing's second disappointment with Libreville in a short period of time. Although, the Bélinga fiasco, and Addax's affair were not caused by the Chinese government but by some of its state-owned companies, the involvement of the former, through its embassy, in the most delicate negotiations related to these deals and eventual cancelations, contributed to feeding anti-China sentiments in Gabon.

Today, the Gabonese government is in the process of transferring the Bélinga concession to BHP (Broken Hill Proprietary) Billiton, an Australian company that will 
first organise a consultation to evaluate the size and quality of the mine as the last assessment was made in the 1960s and is thus considered to be out-dated and unreliable (Interview 2, January 2014). But the introduction in 2013 of a new Gabonese mining code may complicate the picture. And other competitors, based in Congo Brazzaville or in Cameroon, are also interested in exporting Bélinga's iron ore through other channels, including Cameroon's southern harbour of Kribi. In any event, the battle for Bélinga is far from over.

\section{Gabonese government and society's main grievances}

The Gabonese government has remained very reluctant to make public any strong grievances against China or Chinese companies. The need to keep a positive diplomatic relationship with China as an important emerging partner has clearly been the main reason of this discretion. Both sides have a vested interest in deepening their co-operation, not only to successfully complete the existing projects but to stimulate new ones.

However, while subdued, the Gabonese government has not been shy from acting in order to correct situations that it has perceived as unhealthy. In other words, the Sino-Gabonese "honey moon" is over (Interview 3, January 2014). For instance, without singling out the Chinese companies, in 2010, it imposed a strict ban on exports of unprocessed wood, putting a partial end to timber exploitation seen as unsustainable. In 2005, 80 per cent of China's timber imports from Gabon disregarded the law or were involved ub tax evasion and the bulk of wood, including 60 per cent of all okoume (a tropical wood) exports and 36 per cent of wood exports, was exported raw to China (Centre for Chinese Studies, 2007: 85-86). Although some Chinese operators' illegal practices have continued (pieces of unprocessed timber are still exported), they are better controlled globally. These changes have led to Chinese companies relocating to neighbouring countries such as Cameroon and Congo Brazzaville where log exporting and smuggling is easier (Jansson, 2010; Interviews 6, 7 and 10, January 2014).

Simultaneously, the Gabonese authorities have improved their level of transparency and governance, forcing all external actors, including the Chinese to more often 
comply with the rules. However Chinese companies prefer to continue to operate in isolation: for instance, they have refused to join the Union minière du Gabon (UMIGA, Association of Gabon's mining companies), an organisation created in 2010 that although chaired by a Frenchman working for an US company, is in close contact with the Gabonese government and shares information with companies active in this sector. This is probably for the latter reason that the Chinese companies have preferred to stay out. In order to circumvent this self-protective reaction, the Gabonese authorities have tried to associate Chinese and other foreign contractors. For example, on the Grand Poubara dam project, in order to avoid the use of counterfeit equipment, technical control and certification was attributed to a French company (Interviews 6 and 7, January 2014).

The Gabonese society and NGOs' main grievance against Chinese operators have been the level of secrecy of China-Gabon co-operation (Centre for Chinese Studies, 2007: 90). Another, nearly as important, has been damage or risk of damage to the environment of Chinese projects. As we have seen, on several occasions (oil exploration, Bélinga), local NGOs have been able to mobilise the local and foreign public opinion around this cause and force the Gabonese government to react. There are also a few tensions with the local population as well as the Lebanese community $(5,000)$ as a result of Chinese private firms moving into the formal and informal service and trade sectors (Ndong, 2013). Nevertheless, on the whole, there is much less friction between the local society and Chinese companies than in other African countries.

\section{Grievances of other economic actors (and competitors)}

Grievances expressed by China's competitors in Gabon are naturally stronger than among Gabonese officials or citizens. They particularly target Chinese companies. The Chinese embassy is usually exempted from attack even when projects are closely monitored or supported by the Chinese government. As elsewhere in Africa, China's economic competitors perceive that Chinese companies have a stronger tendency to bend the rules of the game in their advantage.

Not surprisingly, this consideration applies in particular to the use of a Chinese 
workforce in Chinese construction projects. In Gabon, the official quota in any company or project is to hire one expatriate for nine Gabonese workers. In reality, this quota is difficult to meet for reasons mentioned at the beginning of this article: the lack of well-trained and cheap technicians (Interview 5, January 2014). In addition, local workers are reluctant to work for Chinese contractors because they are usually ill paid (60,000 CFA or US\$ 125) and the work is hard ${ }^{10}$. As elsewhere, having accepted this job to save money and living a Spartan life, Chinese contractual workers work long daily shifts (10 hours) in order to complete the project, and their contract, as quickly as possible, creating tension with the local workforce (Centre for Chinese Studies, 2007: 87, 92, Interviews 6 and 10, January 2014). For these reasons, Chinese companies usually enjoy a more lenient treatment, described by many competitors as "exceptional", since in most projects, Chinese workers can represent 25 per cent to 50 per cent of the workforce in the road construction sector for instance.

Urgency has already been mentioned as an argument to wave the rules. However, this reason is rarely included in the initial contract, except perhaps in the Port Môle project where a large number of Chinese workers have been spotted (although details have not been made public). For instance, in the case of the national stadium construction project, which on paper had abided by the usual workforce quotas, the dramatic increase of Chinese workers was approved later, in order to make sure that the project was completed on time for the African Cup of Nations. Some have even accused the Chinese contractor of slowing down work on the construction of the stadium on purpose so as to be able to later impose its conditions (Interviews 6 and 7, January 2014).

Another grievance heard in Libreville is Chinese companies' unfair competition and dubious practices. For instance, in 2013-2014, disguised as imports for construction projects and consequently tax-free, Chinese cement has over-flooded the local market, putting CIMGABON, a subsidiary of the German Company Heidelberg Cement, on the verge of bankruptcy. Protests of the German embassy that has called for a respect of WTO regulations have not yet (in January 2014) put an end to this practice ${ }^{11}$. In 2013 miners of China's Jiahua Mines, which is exploring 
gold and copper in south-western Gabon, were found extracting gold on Morocco's Managem's site (The Report, 2013).

\section{Conclusion}

China has clearly become a crucial partner to Gabon, on par with the United States, the EU or even France. However, Ali Bongo has remained keen not to put all his eggs in the same basket and to use his country's other partners as a leverage to better balance and scrutinise the activities of Chinese companies. In so doing the Gabonese president seems to be adapting and reversing to some extent on his father's "blackmail diplomacy" towards France (Bayart, 1990:49; Obiang, 2007:201-60).

In Gabon, as elsewhere in Africa, China is perceived as a key diplomatic interlocutor. More importantly, it has for at least ten years been a more robust driver of economic development. Some Gabonese government officials even see China as a model for their country's modernisation (Centre for Chinese Studies, 2007: 76). Ready to take bigger risks than others in order to get access to natural resources, Chinese companies have been warmly welcomed to contribute to Gabon's industrial diversification. And in spite of some recent setbacks, Gabon-China economic co-operation will continue to deepen.

However, China's political and economic influence on Gabon should not been exaggerated. Its diplomatic contribution to solving Central Africa's regional crisis (for example in CAR) has remained marginal. Chinese actors still have a limited impact in Gabon as the oil, mining and, to a lesser extent, timber industries (in other words all the strategic sectors) are still mainly controlled by Western, and especially French companies. And China's cultural influence is negligible. While more Gabonese learn English and connect with the US, France's soft power, or what some analysts call "cultural imperialism", will continue to dominate Gabon through its language, its laws and institutions as well as its way of life, with a living standard that is exceptionally high, compared to other former French colonies (Yates, 2008:221). This is a clear impediment to China's influence and soft power in Gabon, forcing its diplomats and companies to master the French language ra- 
ther than convincing the Gabonese to learn Chinese.

In any event, Gabon's case shows that the content and the contours of any African country's partnership with China depends upon itself, its own political vision, its ability to choose and its capacity to well manage the co-operation projects that both sides have agreed upon to launch and implement.

\section{Endnotes}

1. The M'Bembelé manganese mine's reserves are estimated at 26 million tons (out of a total for Gabon of 200 million tons); in 2013, it produced 280,000 tons; production should gradually increase to 1 million tons and last for 30 years (Trésor, 2013); the CICMH has 340 workers including 255 Gabonese (75 per cent) and 85 Chinese (25 per cent); in 2013, COMILOG which French ERAMET is the main stakeholder ( 63.7 per cent) produced 4 million tons manganese. The mineral purity of the M'Bembelé mine is 30-40 per cent, considerably lower than in Moanda, exploited by COMILOG. http://infosgabon.com/?p=3417 22 October 2010. (Interview 11)

2. Gabon has 6,000 MW of undeveloped hydro potential; hydropower provides 75 per cent of Gabon electricity.

3. However, during that trip, according to some sources, the Chinese government refused to invite Ali Bongo to Beijing because of the difficulties emerging around the Bélinga project (see below, Interview 8).

4. A. Gabon's total exports and imports are quoted from the WTO Trade Profiles, while the trade volumes with US, EU, and China are author's calculation based on the percentage suggested by the WTO Trade Profiles.

B. Gabon's trade volumes with France in 2005 and 2008 are extracted from UN Comtrade Database, while their volumes in 2012 are extracted from OECD Stat. Their shares in Gabon's merchandise trade are the author's calculation based on the total exports and imports suggested by the WTO Trade Profiles.

C. In 2005, it refers to EU (25) instead of EU (27). 
AFRICAN

5. Imports from Hong Kong or which are not registered by Gabonese customs explain the difference.

6. The loan will be reimbursed in 20 years with a 7 year grace period and a 2 per cent interest rate. This first section also includes the construction of a bridge to Booué on Ogooué river. This first agreement was signed in September 2013 by the Gabonese Minister of Economy, Luc Oyoubi, and the Chinese ambassador to Gabon, Sun Jiwen (Ntoutoume 2013).

7. Launched by Ali Bongo in 2012 and meeting every year in Libreville, the New York Forum Africa sees itself as the "African Davos".

8. In 2010, France welcomed around 30 per cent $(111,195)$ of all the African students studying abroad; Malaysia was their top Asian destination country with 14,744 (or 4 per cent) of the total (Les notes de Campus France 2013).

9. Total was to overtake Shell again in 2013.

10. The minimum legal monthly salary in the Gabonese private sector has been CFA 80,000 (US\$ 170) since 2006.

11. According to some sources, in 2013, Gabon imported 400,000 tons of cement from China, for a market estimated at 600,000 tons, reducing CIMGABON's production to 200,000 tons (Interview 6).

\section{Bibliography}

Addax Petroleum. 2014. Addax Petroleum announces the signature of a new partnership with the Gabonese Republic. [Online]. Available: https:// www.addaxpetroleum.com/about-us/news/156-addax-petroleum- announces-the-signature-of-a-new-partnership-with-the-gabonese-republic [2014, January 16].

Agence Ecofin. 2014. Addax Petroleum a payé plus de 400 millions \$ de dédommagements au Gabon. [Online]. Available: http:// www.agenceecofin.com/droit-des-affaires/2801-17111-addax-petroleum-apaye-plus-de-400-millions-de-dedommagements-au-gabon [2014, 
January 28].

Agence Nationale des Grands Travaux (ANGT). 2013. Nouveau Port Môle.

[Online]. Available: http://www.angt-gabon.com/l-actualite/ actualites/22299/nouveau-port-mole [2013, July 31].

Alves, A. C. 2008. China and Gabon: A Growing Resource Partnership. China in Africa Report No. 4: The South African Institute of International Affairs, Johannesburg: 23.

Ambassade de la République populaire de Chine au Gabon. 2012. La délégation militaire chinoise conduite par le Chef d'Etat-Major Général Adjoint de l'APL SUN Jianguo effectue une visite de travail en République Gabonaise. [Online]. Available: http://ga.chineseembassy.org/fra/zxxx/ t940020.htm [2012, June 10].

Ballong, S. 2012. Agro-Industrie: Siat et GMG, un deal bien huilé. [Online]. Available: http://www.jeuneafrique.com/Article/JA2672p132-133.xml0/ [2012, April 11].

Banktrack. 2011. Dodgy Deal: Belinga Iron Ore Project, Gabon. [Online]. Available: http://www.banktrack.org/manage/ajax/ems_dodgydeals/createPDF/ belinga_iron_ore_project [2014, April 29].

Bayart, J. F. 1990. France-Afrique: la fin du pacte colonial (France-Africa : The end of the colonial pact). Politique africaine, 39: 47-53.

Belinga Dam, Gabon. [Online]. Available: http://www.internationalrivers.org/ resources/belinga-dam-gabon- 3597 [2014, April 29].

Benquet, P. 2011. La Françafrique, [Documentary Film]. Paris: Compagnie des Phares et Balises.

Cabestan, J. 2014. Personal interview 1. 6 January, Libreville.

Cabestan, J. 2014. Personal interview 2. 7 January, Libreville.

Cabestan, J. 2014. Personal interview 3. 7 January, Libreville. 
AFRICAN

EAST-ASIAN

AFFAIRS

Cabestan, J. 2014. Personal interview 4. 7 January, Libreville.

Cabestan, J. 2014. Personal interview 5. 8 January, Libreville.

Cabestan, J. 2014. Personal interview 6. 9 January, Libreville.

Cabestan, J. 2014. Personal interview 7. 9 January, Libreville.

Cabestan, J. 2014. Personal interview 8. 9 January, Libreville.

Cabestan, J. 2014. Personal interview 9. 9 January, Libreville.

Cabestan, J. 2014. Personal interview 10. 9 January, Libreville.

Cabestan, J. 2014. Personal interview 11. 10 January, Libreville.

Cabestan, J. 2014. Personal interview 12. 10 January, Libreville.

Centre for Chinese Studies. 2007. China's Engagement in Africa: Preliminary Scoping of African Case Studies. Angola, Ethiopia, Gabon, Uganda, South Africa, Zambia. Matieland: University of Stellenbosch, November.

Chan, D. 2014. Olam International to sell part of forestry assets, saw mills in Gabon to China investors. The Strait Times, 24 January.

China Commerce and Trade Press. 2013. China Commerce Yearbook, Beijing.

Chine-Gabon: Un contrat de 120 millions USD pour l'aménagement du Port-Môle de Libreville. 2013. [Online]. Available: http://www.afriquinfos.com/ articles/2013/6/16/chine-gabon-contrat-millions-pour- lamenagement-port -mole-libreville-224027.asp [2013, June 16].

Dittgen, R. 2011a. New Development Cycle through Long-term Investment? China and the Belinga Project in Gabon. EchoGeo, 17, June-August: 218 .

Dittgen, R. 2011b. To Bélinga or not to Bélinga? China's Evolving Engagement in Gabon's Mining Sector. South African Institute of International Affairs, Occasional Paper No. 98, November: 27. 
Farge, E. 2013. Reuters. Sinopec's Addax loses court ruling on Gabon oil licencedocument. [Online]. Available: http://mobile.reuters.com/article/ governmentFilingsNews/idUSL9N0FH00520130913 [2014, June 5].

Gabon: CHEC Nabs Port Mole Land Reclamation Contract. 2013. [Online]. Available: http://www.dredgingtoday.com/2013/06/04/gabon-chec-nabs -port-mole-land-reclamation-contract/ [2013, June 4].

Gabon: Pêche sauvage des chalutiers chinois au large de Mayumba. 2012.

[Online]. Available: http://www.gabonlibre.com/Gabon-Peche-sauvage-des -chalutiers-chinois-au-large-de- Mayumba_a19019.html [2012, August $13]$.

Jansson, J., Burke, C. \& Jiang, W. 2009. Chinese Companies in the Extractive Industries of Gabon \& the DRC: Perceptions of Transparency. Centre for Chinese Studies: Stellenbosch University, August 2009.

Jansson, J. 2009. Patterns of Chinese Investments, Aid and Trade in Central Africa (Cameroon, the DRC and Gabon). A briefing paper by the Centre for Chinese Studies prepared for World Wild Fund for Nature (WWF): Stellenbosch University, August 2009.

Jansson, J. 2010. Pambazuka News. Chinese Investments in Gabon's Extractive Industries. [Online]. Available: http://pambazuka.org/en/category/ africa_china/65779 [2010, July 8].

Les notes de Campus France. 2013. Hors série No. 7, June 2013. [Online]. Available: ressources.campusfrance.org/publi_institu/agence_cf $/$ notes/fr/ note_07_hs_fr.pdf

Michel, S. \& Beuret, M. 2010. La Chinafrique. Paris, Grasset: Fayard/Pluriel.

Ndong, M. 2013. GabonReview. Lebanon business: petite ethnographie des Libanais $d u$ Gabon. [Online]. Available: http://gabonreview.com/blog/ lebanon-business-petite-ethnographie-des-libanais-du-gabon/ [2013, August 8]. 
AFRICAN

Ntoutoume, L. 2013. GabonReview. Un prêt chinois de 64, 8 milliards de CFA pour la route vers Port-Gentil. [Online]. Available: http://

gabonreview.com/blog/un-pret-chinois-de-648-milliards-cfa-pour-la-routevers-port-gentil/ [2013, October 1].

Obiang, J. 2007. France-Gabon. Pratiques clientélaires et logiques d'Etat. Paris: Karthala.

OECD International direct investment database. FDI flows by partner country: France and USA. [Online]. Available: http://stats.oecd.org/Index.aspx? DataSetCode=FDI_FLOW_PARTNER [2014, March 20].

OECD International direct investment database. Total: All commodities. [Online]. Available: http://stats.oecd.org/Index.aspx? DataSetCode $=$ HS1988\# (Accessed April 5, 2014).

Ogandaga, M. 2013. Le Gabon Emergent. Le Gabon Émergent en action: Route Port-Gentil-Libreville début du chantier. [Online]. Available: http:// legabonemergent.over-blog.com/2013/10/le-gabon-Émergent-en- action-route-port-gentil-libreville-début-du-chantier.html [2013, October 9].

Openshaw, D. 2012. Minority Voices Newsroom. Gabon: Mining, Dam and Repression. [Online]. Available: http://www.minorityvoices.org/ news.php/fr/1138/gabon-mining-dams-and-repression [2014, April 14].

People's Liberation Army (PLA) Daily .2009. China-Gabon joint humanitarian medical rescue operation kicks off. [Online]. Available: www.english.chinamil.com.cn/site2/special-reports/2009- 06/22/ content_1826092.htm [2009, June 22].

SIAT. 2012. Siat entered into a partnership with the Singaporean base GMG Global Ltd $(G M G)$. [Online]. Available: http://www.siat-group.com/ news/siat-entered-into-a-partnership-with-the-singaporean- based-gmgglobal-ltd-gmg/ [2014, April 14].

SIAT Gabon. [Online]. Available: http://www.siatgabon.com/plantations/ [2014, April 14]. 
The Report: Gabon 2013, Mining and Industry: Oxford Business Group. [Online]. Available: http://www.oxfordbusinessgroup.com/news/added-potentialgoing-beyond-manganese-other-minerals [2014, April 29].

Trésor, Direction générale. 2013. Le secteur pétrolier au Gabon, Publications des services économiques, Ambassade de France au Gabon, Service économique, December 2012.

Trésor, Direction générale. 2013. Le secteur minier au Gabon, Publications des services économiques, Ambassade de France au Gabon, Service économique, July 2013.

Trouble in Belinga: An Update. 2009. [Online]. Available: http:// www.rainforestfoundationuk.org/Belinga_Update [2014, April 14].

United Nations, UN Comtrade Database. 2013. [Online]. Available: http:// comtrade.un.org/data/ [2014, April 15].

Wikileaks. 2008. Gabon: Africom Commander's Successful Visit. [Online]. Available: www.cablegatesearch.net/cable.php?id=08LIBREVILLE19 [2008, January 11].

World Investment Report. 2013. Annex Table 01 - FDI inflows, by region and economy, 1990-2012. [Online]. Available: http://unctad.org/en/pages/ DIAE/World\%20Investment\%20Report/Annex-Tables.aspx $\quad$ [2014, March 20].

World Trade Organization. Trade Profiles: 2006 - 2013. [Online]. Available: http://www.wto.org/index.htm [2014, June 5].

Yates, D. A. 1996. The Rentier State in Africa: Oil-Rent Dependency and Neocolonialism in the Republic of Gabon. Trenton \& Asmara: Africa World Press.

Yates, D. 2008 French Puppet, Chinese Strings?, in Ampiah, K. \& Naidu, S. (eds). Crouching Tiger, Hidden Dragon? China and Africa. Scottsville: University of KwaZulu-Natal Press. 208-223. 